\section{'Floribelle M9': An Autumn Celery Cultivar for Florida}

\author{
E.A. Wolf ${ }^{1}$ and B. Scully ${ }^{2}$ \\ Everglades Research and Education Center, Institute of Food and \\ Agricultural Sciences, University of Florida, Belle Glade, \\ FL 33430-8003
}

Additional index words. Apium graveolens, bacterial leaf spot, early blight

On the Histosols of the Everglades agricultural area, celery (Apium graveolens L.) production is a year-round activity. Production of transplants begins in late May and proceeds for the next 6 or 7 months. Ten- to 15 -week-old seedlings are transplanted to the field and grown for another 12 to 16 weeks before harvest, The harvest begins in November and continues to the following June. The celery production season is roughly divided into four periods, each with seasonaly adapted cultivars. Over the past 10 years, the production area has ranged from $\approx 3000$ to 4500 ha, with an annual value of $\$ 20$ to $\$ 45$ million.

The autumn celery crop is transplanted in hot, humid, rainy weather that is conducive to serious disease epiphytotics. Cultivars developed for this production period must be adapted to these climatic conditions and carry resistance to the disease pathogens favored by this environment. 'Floribelle M9' was selected for improved adaption and horticultural quality, with primary emphasis on resistance to early blight caused by Cercospora apii Fres. and bacterial leaf spot incited by Pseudomonas cichorii (Swingle) Stapp.

\section{Origin}

'Floribelle M9' was developed by a pedigree breeding method that featured single plant selection from the $F_{2}$ through the $F_{5}$. A superior $F_{5}$ individual was selected and designated Mg-1-16-1; subsequent generations were bulked and field tested as M9-116-1CM (Fig. 1). The name 'Floribelle M9' was assigned in the $F_{8}$ generation and indicates Belle Glade, Fla., as the site of origin. M9 is the pedigree code for the original $F_{2}$

Received for publication 24 Jan. 1992. Accepted for publication 8 July 1992. Florida Agricultural Experiment Station Journal Article no. R-02123. This research was supported in part by the Florida Celery Exchange. We appreciate the help of A. Duda and Sons, D.D. Division Farms. and South Bay Growers. The cost of publishing this paper was defrayed in part by the payment of page charges. Under postal regulations, this paper therefore must be hereby marked advertisement solely to indicate this fact.

'Professor Emeritus.

*Assistant Professor, to whom reprint requests should be addressed. population that was derived from a cross made in 1969 between elite breeding lines EES 1624-2 and EES 1625-2. EES 1625-2 had superior resistance to early blight and bacterial leaf spot. Both of these lines were derived from a cross made in 1960 between a selection from Florida 2-13, which originated from a single plant selection out of 'Utah 52-70' (G. Talbott, personal communication), and EES 327-4 (Fig. 1). EES 3274 traces back to Cornell 50-256-2. which was

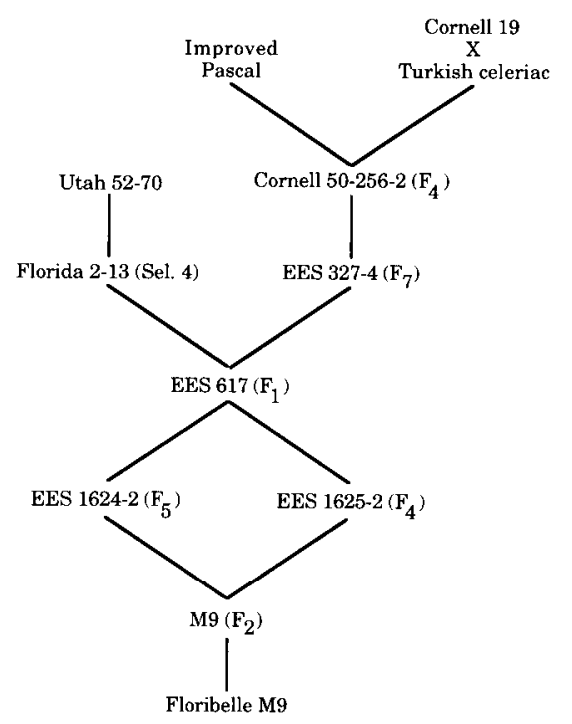

Fig. 1. Pedigree of 'Floribelle M9'. an $\mathrm{F}_{4}$ progeny derived from an outcross between 'Improved Pascal' and a breeding line derived from a cross between 'Turkish Celeriac' and 'Cornell 19' (Fig. 1). 'Floribelle M9' is derived from the same $F_{2}$ population as 'Earlibelle' and 'June-Belle' (Wolf, 1970a, $1970 \mathrm{~b}$ ) and is released as a replacement for 'Earlibelle' and as an alternative to 'Florida 2-14' early in the winter production season.

\section{Description}

'Floribelle M9' has an intermediate growth habit between the Crystal Jumbo and the Ordinary Utah phenotypes (U.S. Dept. Agriculture, 1981). In Florida, 'Floribelle M9' is a midseason cultivar that matures 92 to 99 days from transplanting. Plants are 64 to 76 $\mathrm{cm}$ tall, with an average height of $70 \mathrm{~cm}$ when grown on a row spacing of $60 \mathrm{~cm}$, with 17 to $20 \mathrm{~cm}$ between plants. In more openly spaced cropping systems or in border rows, plants are $\approx 6$ to $8 \mathrm{~cm}$ shorter. The trimmed and stripped mature stalks in the " $2,2 \frac{1}{2}, 3$ and 4" dozen-sized market classes range from six to 12 outer petioles and are $\geq 40 \mathrm{~cm}$ long when measured from leaf tip to petiole base. Inner petioles range from four to six, with $\approx 20 \%$ of the petioles shorter than $40 \mathrm{~cm}$. Commonly, 'Floribelle M9' has a noticeably more robust appearance than either 'Earlibelle' or 'Florida 2-14' (Fig. 2). Stalk shape is similar to 'Tall Utah 52-70 R Improved' and somewhat more open than 'Florida 214' (Fig. 2). The heart formation of 'Floribelle M9' is not as full as 'Tall Utah 52-70 $\mathrm{R}$ Improved' and averages between three to four heart leaves on Florida Histosols. The petiole length, as measured from the petiole base to the first node, averages $23.4 \pm 1.4$ $\mathrm{cm}$ and is more uniform across environments than either 'Earlibelle' or 'Florida 2-14' (Table 1). Petiole width, measured at the midpoint between petiole wing and the first node (U.S. Dept. Agriculture, 1981), averages 1.8 $\pm 0.04 \mathrm{~cm}$ (Table 1), with a cross-sectional petiole thickness of 8 to $12 \mathrm{~mm}$. 'Floribelle M9' is also characterized by more attenuation toward the wing and increased color

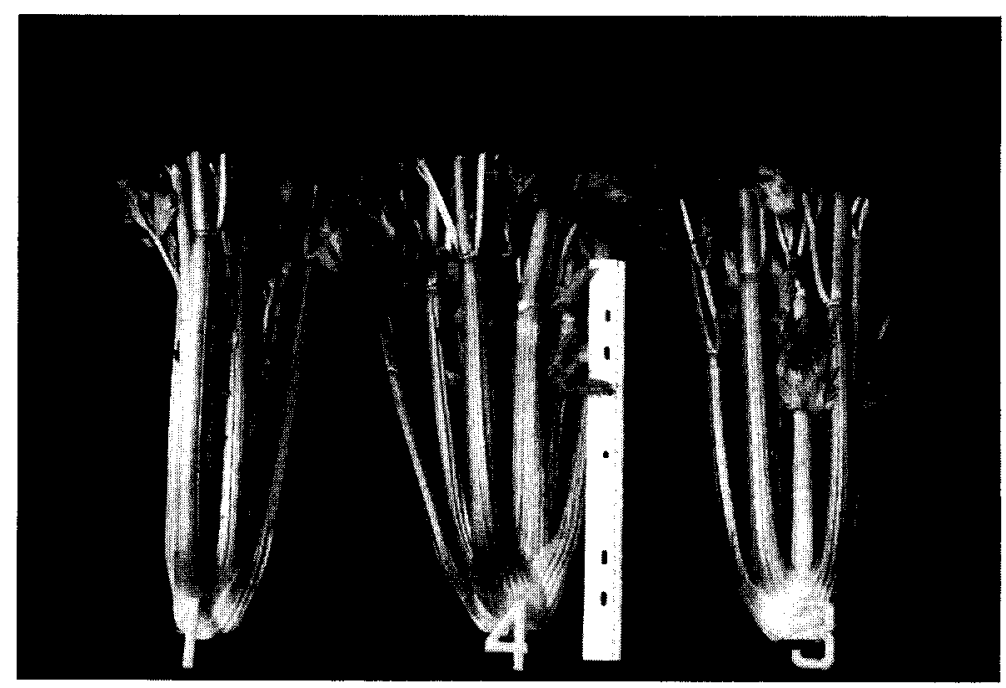

Fig. 2. Typical trimmed mature stalks of 'Florida 2-14' (1), 'Floribelle M9' (4), and 'Earlibelle' (3) taken from production fields in the Everglades agricultural area. The ruler is $30 \mathrm{~cm}$ long. 
Table 1. Comparison of uality traits and yield of 'Floribelle M9' to the standard cultivars or breeding lines.

\begin{tabular}{|c|c|c|c|c|c|c|c|}
\hline \multirow[b]{2}{*}{$\begin{array}{l}\text { Cultivar }{ }^{2} \\
\text { or line }\end{array}$} & \multicolumn{2}{|c|}{ Petiole } & \multicolumn{2}{|c|}{ Cracks } & \multirow[b]{2}{*}{$\begin{array}{l}\text { Pith }^{v} \text { count } \\
\text { (no.) }\end{array}$} & \multirow[b]{2}{*}{$\begin{array}{l}\text { Browned } \\
\text { stems } \\
\text { (no.) }\end{array}$} & \multirow[b]{2}{*}{$\begin{array}{c}\text { Yicld } \\
\text { (boxes/ha) }\end{array}$} \\
\hline & $\begin{array}{c}\text { Length }^{y} \\
(\mathrm{~cm} \pm \mathrm{st})\end{array}$ & $\begin{array}{c}\text { Width }^{x} \\
(\mathrm{~cm} \pm \mathrm{SE})\end{array}$ & $\begin{array}{c}\text { Transverse } \\
\text { nodal }^{w} \\
\text { (no.) }\end{array}$ & $\begin{array}{l}\text { Longitudinalw } \\
\text { (no.) }\end{array}$ & & & \\
\hline Floribelle M9 & $23.4 \pm 1.38$ & $1.82 \pm 0.04$ & $4.88 \pm 2.00$ & $5.30 \pm 4.27$ & $3.40 \pm 3.50$ & $1.50 \pm 2.31$ & $1036 \pm 156$ \\
\hline Florida 2-14 & $24.7 \pm 1.58$ & $1.71 \pm 0.06$ & $3.43 \pm 0.85$ & $3.17 \pm 2.63$ & $3.15 \pm$ & $2.13 \pm 2.17$ & $920 \pm 163$ \\
\hline Earlibelle & $25.0 \pm 3.04$ & $1.66+0.07$ & $1.15+0.53$ & $2.30 \pm 0.50$ & $3.56 \pm 4.71$ & $1.28 \pm 0.77$ & $958 \pm 153$ \\
\hline EES 2192 & $23.6 \pm 0.97$ & $1.73 \pm 0.06$ & $4.70 \pm 2.14$ & $4.73 \pm 3.41$ & $11.13 \pm 11.75$ & $3.00 \pm 2.17$ & $1029 \pm 160$ \\
\hline
\end{tabular}

${ }^{\mathrm{z}}$ Results are based on six replications in four site-year environments, unless otherwise noted.

${ }^{\mathrm{y}}$ Samples based on 10 outer petioles taken randomly from trimmed, stripped mature stalks, with length measured from the first node to the base of the petiole.

${ }^{\mathrm{x}}$ Sample based on same 10 petioles used for length measurements. Width measured at the midpoint between the first node and the petiole wing.

${ }^{\mathrm{w}}$ Based on the number of affected petioles from 10 trimmed, unstrippcd mature stalks; results based on three site-year environments.

${ }^{\mathrm{v}}$ Based on the count from 10 stripped, trimmed, and randomly selected marketable stalks, with petioles cut $3.8 \mathrm{~cm}$ from the base.

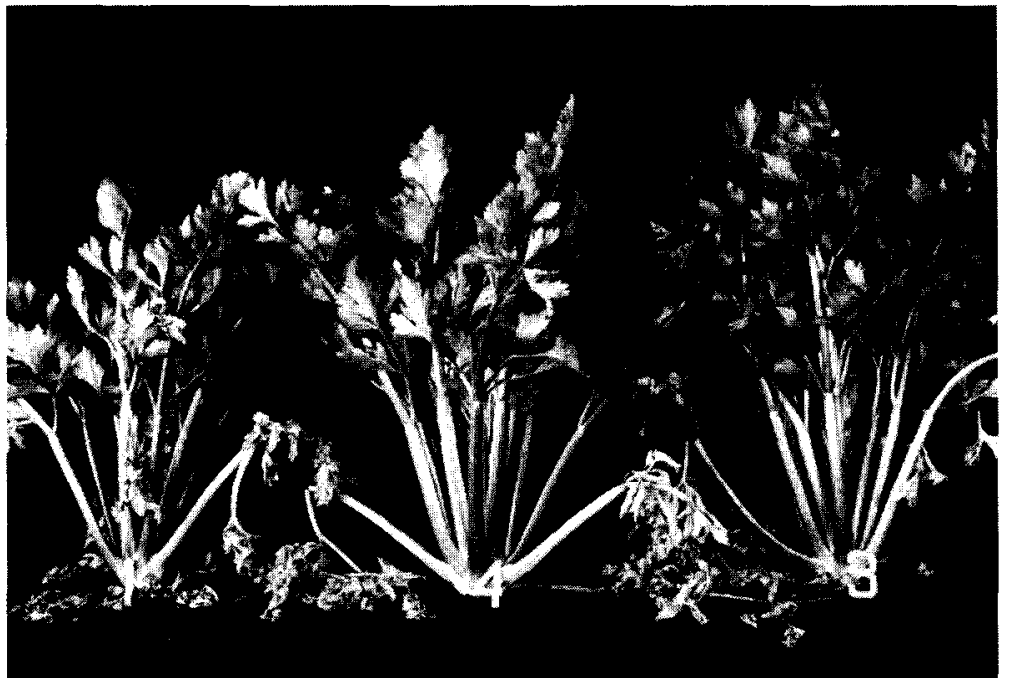

Fig. 3. Leaf blight reaction of 'Florida 2-14' (1), 'Floribelle M9' (4), and 'Earlibelle' (3) grown without fungicide protection.

persistence toward the petiole base than 'Earlibelle' (Fig. 2). Cross-sectional petiole shape is moderate to slightly cupped (U.S. Dept. Agriculture, 1981). Petioles and leaves are a moderately glossy and a medium green, respectively, with no anthocyanin coloring. Petioles are moderately ribbed with only slight stringiness (U.S. Dept. Agriculture, 1981).

'Floribelle M9' exhibits differential response to abiotic disorders induced by plant nutrition. It is more susceptible to boronrelated transverse cracking in the nodal region and longitudinal cracking than other genotypes tested, but only 'Earlibelle' was significantly less susceptible (Table 1). Most of the cracks occur on the outer petioles, which are commonly stripped at harvest. 'Floribelle M9' is susceptible to blackheart caused by inadequate Ca levels. These nutritional disorders that reduce crop quality on the Histosols of southern Florida can be reduced with careful management of plant nutrition. Genotype $\times$ nutrition interactions would likely differ between mineral and organic soils.

Susceptibility to pithiness and brown stem is equivalent for 'Floribelle M9' and the comparison standards, while the yield trend is higher but not significantly (Table 1). 'Floribelle M9' is more resistant to the complex of early and bacterial blight disorders than either 'Earlibelle' or 'Florida 2-14' (Fig. 3). 'Floribelle M9' was also selected for resistance to seed thermodormancy and vigor and uniform seedling growth in the summer months. Bolting tolerance is not required in this production slot.

\section{Availability}

'Floribelle M9' is a public release from the Univ. of Florida. Breeders seed was deposited with the Florida Foundation Seed Producers, Inc., Box 309, Greenwood, FL 32433 , and stock seed with the Florida Celery Exchange. A commercial seed lot was also sent to the U.S. Dept. of Agriculture (USDA) Germplasm Repository in Geneva, N.Y. For research purposes, small seed samples are available from B.S. or the USDA.

\section{Literature Cited}

U.S. Department of Agriculture. 1981. Objective description of variety: Celery (Apium graveolens L. var. dulce (Miller) Pers.), Exhibit C. Form LMGS-470-51 (8-81), U.S. Dept. Agr., Beltsville, Md.

Wolf, E.A. 1970a. 'Earlibelle', A new early blight resistant celery. Florida Agr. Expt. Sta. Circ. S-207, Gainesville.

Wolf, E.A. 1970b. 'June-Belle', A new early blight resistant celery for spring harvest in South Florida. Florida Agr. Expt. Sta. Circ. S-208, Gainesville. 